\title{
O DILACERAMENTO DA FAMÍLIA TRADICIONAL ATRAVÉS DA CONSUMAÇÃO DO DESEJO EM O CASAMENTO, DE NELSON RODRIGUES
}

\author{
TRADITIONAL FAMILY'S LACERATION THROUGH CONSUMMATION \\ OF DESIRE IN O CASAMENTO, BY NELSON RODRIGUES
}

\author{
Jhonatan Leal da COSTA (UEPB) \\ Hermano de França RODRIGUES (UFPB)
}

\begin{abstract}
Resumo: Em 1966, no auge da ditadura militar no Brasil, Nelson Rodrigues teve o seu romance, $O$ casamento, publicado há apenas um mês, censurado. Através de uma portaria assinada em 12 de outubro por Carlos Medeiros Silva, ministro da Justiça do marechal Castello Branco, veio a determinação da apreensão do romance rodriguiano das livrarias brasileiras, sob o argumento de que a dita narrativa era portadora de discursos com "torpeza nas cenas descritas e linguagem indecorosa", um verdadeiro "atentado contra a organização da família" (RODRIGUES, 2016, p. 264). Passados mais de cinquenta anos da publicação do único romance assinado com o nome de batismo do mais conceituado dramaturgo brasileiro moderno, notamos como os temas apresentados em $O$ casamento continuam a afrontar o moralismo do Brasil vigente. Ao representar uma família tradicional nos preparativos para o matrimônio de um dos seus membros, Nelson Rodrigues expõe, como corrobora Alexandre Pianelli Godoy (2012, p. 106), o paradoxo entre "o sentimento de descrédito da instituição familiar dentro da própria família" e a inversamente proporcional valoração ideológica, por parte dos mesmos parentes, de dogmas conservadores, patriarcais. Nesse sentido, objetivamos, neste trabalho, analisar como as personagens do romance em tela negociam com a normatividade paterna, autoritária, religiosa, misógina e homofóbica, tão em desacordo com seus desejos conscientes e/ou inconscientes de masoquismo, sadomasoquismo, exibicionismo, voyeurismo, homoafetividade, adultério, incesto e abuso sexual. Montado o drama da família tradicional burguesa, dividida entre a regularização e a secularização, compreenderemos as tensões dos desejos de "moralidade" contra os de "imoralidade" com base na Psicanálise freudiana, através de obras como Totem e tabu (2012), O mal-estar na civilização (2010) e Os três ensaios sobre a teoria da sexualidade (2016), as quais problematizam a construção das proibições sociais relacionadas ao sexo, o sacrifício da pulsão de desejo individual em detrimento da harmonia da coletividade e o modo como a sexualidade vem a ser organizada, respectivamente. Conforme apontaram Edmundo Gómez Mango \& J-B Pontalis (2013), bem como Jean Bellemin-Noël (1978, p. 19), acreditamos ser a teoria psicanalítica fundamental no processo de decifração do criptograma em que se transforma, "sem o saber nem querer", o texto literário. Ao lado da bibliografia psicanalítica, também contribuirão, para os nossos aprofundamentos, as pesquisas desenvolvidas no âmbito da crítica literária por Sábato Magaldi (1992), Jean-Marie Thomasseau (2012), Alexandre Godoy (2012), Victor Pereira (2012), Ângela Dias (2013), dentre outros. Nas considerações desse artigo, apresentaremos achados que desembocam os desejos das personagens de $O$ casamento em condições punitivas, sentimento de culpa, hipocrisia, crime, morte, tragédia e deterioração da instituição familiar, revelando ser o próprio título da obra a representação de um modelo organizacional que põe em xeque o que pode haver de mais controverso na essência humana: o erotismo e a sexualidade.
\end{abstract}

Palavras-chave: Psicanálise. Família. Desejo. Nelson Rodrigues.

Abstract: In 1966, peak moment during Brazil's military dictatorship, Nelson Rodrigues had his novel $O$ Casamento censored just one month after its publication. Through a decree signed by Carlos Medeiros Silva, Minister of Justice Marshal Castello Branco, on October 12th, came the order to remove the novel from all Brazilian libraries, under the allegation that the narrative was filled with "turpitude and scenes depicted with incredibly indecorous language." a truly "affront against family's organization" 
(RODRIGUES, 2016, p. 264). Fifty years past the publication of the novel, the only one to be signed by the most acclaimed modern Brazilian play-writer, we still can see how the issues addressed in $O$ Casamento still continue to shake Brazilian moralism. By representing a traditional family during the preparations for one of its member's wedding ceremony, Nelson Rodrigues showcases, as pointed by Alexandre Pianelli Godoy (2012, p. 106), the paradox between "the feeling of discredit of the family as an institution, inside the own family" and the inversely proportional, ideological valorization of conservative and patriarchal dogmas by the family members. In this regard, we intend, in this paper, to analyze how the characters of the novel deal with the authoritarian, religious, misogynist and homophobic norms, that directly affront their conscious or unconscious desires of masochism, sadism, exhibitionism, voyeurism, homosexuality, incest, adultery and rape. Once the traditional bourgeoisie family drama is depicted, divided between normalization and secularization, we will comprehend the tensions derived from conflicting desires of "morality" and "immorality" based on Freudian Psychoanalysis, through works as Totem e tabu (2012), O mal-estar na civilização (2010) and Os três ensaios sobre a teoria da sexualidade (2016), which question the construction of social restrictions related to sex, the sacrifice of one's individual desires at the expense of collective harmony and the way sexuality as a whole is established, respectively. As pointed by Edmundo Gómez Mango \& J-B Pontalis (2013), as well as by Jean Bellemin-Noël (1978, p. 19), we believe that the psychoanalytical theory is fundamental in the process of deciphering the code in which the literary text is transformed into. In addition to psychoanalytical references, other researches will contribute to our goals, such as the ones developed in the field of literature by Sábato Magaldi (1992), Jean-Marie Thomasseau (2012), Alexandre Godoy (2012), Victor Pereira (2012), Ângela Dias (2013), among others. During the development of this paper, we present findings that direct the characters' desires to punishable situations, guilt, hypocrisy, crime, death, tragedy and discredit of the family institution, as the title of novel appears to be the representation of an organizational structure that calls into question the most controversial parts of human life: eroticism and sexuality.

Keywords: Psychoanalysis. Family. Desire. Nelson Rodrigues.

\section{Convite}

Publicado em 1966, dois anos após a eclosão da ditadura militar no Brasil (1964-1985), $O$ casamento, de Nelson Rodrigues, encontra na contemporaneidade um contexto sociopolítico não muito diferente do de seu ano de lançamento. Naquela época, Carlos Medeiros Silva, ministro da Justiça do marechal Castello Branco, assinou uma portaria em 12 de outubro de 1966 determinando a apreensão do que havia restado do romance nas livrarias, visto que a primeira tiragem havia chegado há pouco mais de um mês. Ancorada nos valores da Marcha da Família com Deus pela Liberdade, a sentença expressa no documento explicava a motivação da censura: "pela torpeza das cenas descritas e linguagem indecorosa em que está vazado", $O$ casamento se configuraria, de acordo com os militares, como um verdadeiro "atentado" contra “a organização da família” (RODRIGUES, 2016, p. 264). A medida contou com o apoio da população conservadora, assim como com o de expressivos jornais. $O$ Globo de 19 de outubro daquele ano, através de um editorial intitulado "Um dever de consciência", veio a público defender a postura do governo ao alegar que, acima da liberdade de criação de artistas e 
escritores, devem estar "protegidos pelas autoridades os princípios basilares de nossa organização social, e entre estes o do matrimônio.” (ibdem, p. 266).

O casamento recebeu liberação oficial em 1967, quando o potencial de best-seller do livro já havia sido abalado pelas confiscações e intimidação da Polícia Federal. Apesar disso, um significativo segundo reencontro da obra com o público ocorreu em 1975, quando Arnaldo Jabor adaptou a narrativa para o cinema, seguindo a onda do sucesso obtido, dois anos antes, com a filmagem de Toda nudez será castigada. Agora, em 2017, após o deflagrar de inúmeros escândalos de corrupção por parte dos governantes brasileiros, com culminância no impeachment da ex-presidente Dilma Rousseff, marchas em defesa da moralidade e dos valores da família tradicional, assim como ecos saudosistas clamando o retorno da ditadura, voltaram a ocupar as ruas do país, arquitetando, na esfera da sociedade contemporânea, o cenário ideal para o relançamento de $O$ casamento, concretizado pela editora Nova Fronteira em 2016.

Único romance de Nelson Rodrigues assinado pelo nome do próprio autor - o qual costumava fazer uso de pseudônimos, como o de Suzana Flag -, O casamento apresenta temas que continuam a afrontar o moralismo da família tradicional brasileira, compreendida, neste trabalho, como aquela constituída nos moldes hegemônicos, com núcleo familiar estruturado por um casal ou um sujeito heterossexual que anseia originar descendentes com valores socioafetivos iguais.

No romance em discussão, Sabino, um bem-sucedido corretor imobiliário, se vê, na véspera do casamento da sua filha, Glorinha, confrontado por fantasias e desejos sexuais considerados por ele, e pelo grupo do qual faz parte, como inaceitáveis. Ao descobrir que o seu futuro genro, Teófilo, possui conduta homoafetiva, Sabino passa a duvidar se deveria ou não preservar a cerimônia do casamento de sua amada filha, para quem direciona, conflituosamente, um sentimento incestuoso. Na construção dessa diegese, é a véspera da consumação de um matrimônio a responsável por aflorar os instintos libidinosos não só do protagonista, como das demais personagens, a exemplo da própria noiva, Glorinha, que não conserva sua virgindade até o altar, e se entrega, de maneira inesperada, a experiências adúlteras, homoafetivas e de sexo a três.

O paradoxo de personagens financeiramente estáveis, revelado na constante luta de seus valores contra os seus desejos, é a tônica da maior parte das narrativas de Nelson Rodrigues. A insatisfação sexual, a libido desenfreada e a crise que ronda os universos do masculino e do feminino são temas frequentemente inseridos por este autor no contexto familiar, a exemplo das peças Vestido de Noiva (1981a), O Beijo no Asfalto (1989) e Álbum de Família (1981b), 
ainda que, na perspectiva estética, essas manifestações nem sempre apareçam da mesma forma. Para Alexandre Pianelly Godoy (2012, p. 101), "parece ter ficado evidente a importância da família como um dos temas centrais da dramaturgia de Nelson Rodrigues". "Nelson não temia repetir-se, preferindo a clareza dos pontos de vista insistentemente retomados", esclarece Sábato Magaldi (2010, p. 21).

O escritor pernambucano, mais conhecido como dramaturgo, posiciona suas personagens no interior da família burguesa advinda da decadência da extensa família aristocrática. "Podese dizer que são famílias aristocráticas em processo de aburguesamento, ressentidas com a progressiva perda dos valores tradicionais (conservadores) e com o advento de um individualismo nada promissor" (GODOY, 2012, p. 103).

Com ideologia centrada na defesa da moral familiar como representante de um EstadoProvidência burguês, o Estado Novo, ainda que tenha encerrado seu percurso na segunda metade dos anos 1940, propagou sua influência pelas décadas seguintes. "A cultura moral pública misógina, racista e fundamentalista católica que conviveu com as ideias de inclusão social total" expusera as tensões ambíguas e contraditórias dos valores familiares brasileiros, dividido entre uma cultura da moral pública e uma cultura moral privada. (GODOY, 2012, p. 101).

A ideia defendida por Alexandre Godoy (2012, p. 103) em Nelson Rodrigues: o fracasso do moderno no Brasil é a de que a família burguesa, por ser hegemônica e atender aos ideais da elite, deveria ser "a tradução do sucesso dos valores burgueses modernos daquela época, mas acabam por vivenciá-los como desilusão", como fracasso, o que é expresso em seus comportamentos frustrantes e controversos plasmados pelas personagens rodriguianas. Perspectiva que, para nós, é bastante problemática.

Ao construir um plano argumentativo que enseja justificar os conflitos, tensões e infortúnios sofridas pelas personagens de Nelson Rodrigues como sendo provenientes das incongruências da ideologia burguesa e das sociedades de massas dela resultante, como a baixa classe média, Godoy desconsidera a inerência, universalidade e atemporalidade dos conflitos psíquicos e sexuais humanos, para quem "a tradução do sucesso de valores", segundo Freud (2010, p. 60), é impraticável, visto estarmos diante de uma "frustração cultural" geral, que "domina o largo âmbito dos vínculos sociais entre os homens".

Nesse viés, em dissonância à tese de Godoy, este trabalho, ao se firmar na teoria psicanalítica, desejará expor que os dramas vivenciados pelas personagens rodriguianas, sob o corpus do romance $O$ casamento, não podem ser reduzidos unicamente a efeitos do implemento 
da modernidade no Brasil, caracterizada por Godoy (2012, p. 23), dentre outras questões, pela "família burguesa de elite como representante moral de um Estado-Providência liberal e conservador". Como analisaremos nas páginas seguintes, as diretrizes norteadoras das ações das personagens de Nelson Rodrigues são muito mais de ordem psíquica e, ainda que as conjunturas políticas e históricas se façam importantes para o modo como a psique humana venha a ser estruturada, não podemos negar os impactos psicológicos de toda uma herança cultural - como arquiteta Freud (2012) em "Totem e tabu" -, de cunho patriarcalista, que está para muito além do surgimento do Estado Novo ou da ascensão da burguesia no Brasil.

Desse modo, objetivamos, neste artigo, analisar, por um viés psicanalítico, como as personagens de $O$ casamento negociam com a normatividade patriarcal, autoritária, religiosa, misógina e homofóbica, tão em desacordo com os seus desejos conscientes e/ou inconscientes de masoquismo, sadomasoquismo, exibicionismo, voyeurismo, homoafetividade, adultério, incesto e abuso sexual, buscando compreender, através do que está posto no registro literário em tela, os porquês e/ou motivações mascaradas nas/pelas atitudes controvérsias dos seres representacionais talhados por Nelson Rodrigues.

Diante do drama da família tradicional, patriarcalista, dividida entre a regularização e a secularização, compreenderemos, em um primeiro tópico, as tensões dos desejos de "moralidade" contra os de "imoralidade", através dos tratados de Sigmund Freud, mais especificamente por meio dos textos "Totem e tabu" (2012), "O mal-estar na civilização" (2010) e "Três ensaios sobre a teoria da sexualidade" (2016), os quais problematizam a construção das proibições sociais relacionadas ao sexo, o sacrifício da pulsão de desejo individual em detrimento da harmonia da coletividade e o modo como a sexualidade vem a ser organizada, respectivamente.

Em um segundo tópico deste trabalho, nos deteremos na análise, em separado, do protagonista Sabino e de sua filha Glorinha, confrontando-os, por meio da trama narrativa, com as demais personagens e consigo mesmas, no desejo de perceber como as atitudes, dizeres e desejos dessas personagens refletem e/ou refutam a teoria freudiana. Conforme apontaram Edmundo Gómez Mango \& J-B Pontalis (2013), bem como Jean Bellemin-Noël (1978, p. 19), acreditamos ser a teoria psicanalítica fundamental no processo de decifração do criptograma em que se transforma, "sem o saber nem querer", o texto literário.

Ao lado da bibliografia psicanalítica, também contribuirão, para os nossos aprofundamentos, as pesquisas desenvolvidas no âmbito da crítica literária por Sábato Magaldi 
(1992), Jean-Marie Thomasseau (2012), Alexandre Godoy (2012), Victor Pereira (2012) e Ângela Dias (2013).

Por fim, em um terceiro e último tópico, fecharemos a análise de $O$ casamento com o estudo psicanalítico do desfecho das principais personagens, mais uma vez sendo guiados pelo arco narrativo de Sabino e Glorinha, os quais nos desembocarão em debates sobre culpa, punição, crime, tragédia e deterioração da estrutura da família tradicional.

\section{Preparativos}

\section{O desejo normatizado}

O romance $O$ casamento, como o próprio título supõe, traz como tema central a união estabelecida formalmente entre um casal prestes a constituir uma nova família: Glorinha e Teófilo. Representado pelo modelo cristão do Ocidente de meados do século XX, o início do vínculo matrimonial entre as referidas personagens deflagra, na progressão romanesca, uma série de crises, mentiras, enganos e controvérsias a que os futuros noivos, seus parentes e amigos estão entrelaçados. Seduzidos pelos encantamentos do sexo despudorado e pelas promessas do desejo, os sujeitos arquitetados em $O$ casamento vão, um a um, rompendo com os códigos sociais, parentais, filiais e matrimoniais firmados, pondo em questão a eficiência das normas e do sucesso da instituição familiar nos arranjos tradicionais.

Foi no interior dessas tensões entre o regimento comportamental determinado pela família, pela religião, pela cultura, pela história e pela sociedade, constantemente em desacordo com as vontades advindas da alma, do desejo, da libido e do interior mais íntimo e pessoal de cada sujeito, que Freud alicerçou a coluna da teoria psicanalítica.

Ao tratar dos males que originam a infelicidade humana, em "O mal-estar na civilização", obra publicada em 1930, o médico austríaco apontou que, na raiz do sofrimento do homem moderno, está "a prepotência da natureza, a fragilidade de nosso corpo e a insuficiência das normas que regulam os vínculos humanos na família, no Estado e na sociedade" (FREUD, 2010, p. 43). Em O casamento, a véspera da grande entrada de Glorinha na igreja deixa Sabino, o pai da noiva, em conflito com as diretrizes do seu próprio matrimônio: "E, de repente, na escada, começou a ter nojo, simplesmente nojo, da [sua] mulher" (RODRIGUES, 2016, p. 08, grifo nosso).

Nesse sentido, Freud (2010, p. 45) argumenta que, incapaz de suportar a medida de privação imposta pela sociedade, em favor de ideais culturais, o sujeito se torna propenso a 
vivenciar estados de infelicidade. "Não acredito mais em nada, em ninguém. E só quero uma coisa: morrer” (RODRIGUES, 2016, p. 99). Apesar disso, a regulamentação social, como exemplificada pela personagem de Sabino, o qual, por mais que sinta nojo da mulher, se vê obrigado a tolerá-la para que os dogmas do casamento cristão sejam preservados, se faz necessária, na perspectiva freudiana, para a manutenção da civilização.

São instituições como o casamento, a religião e o Direito que nos afastam de antepassados selvagens e protegem os nossos vínculos, ainda que a nossa carga de subjetividade/individualidade precise ser reprimida em prol da soberania e do bem-estar coletivo:

Talvez possamos começar afirmando que o elemento cultural se apresentaria como a primeira tentativa de regulamentar essas relações. Não havendo essa tentativa, tais relações estariam sujeitas à arbitrariedade do indivíduo, isto é, aquele fisicamente mais forte as determinaria conforme seus interesses e instintos. (FREUD, 2010, p. 56).

Desse modo, controlado e interditado por leis externas, o sujeito é obrigado a assimilar, desde a mais tenra infância, condutas pré-estabelecidas pela sociedade que o autorizam ou desautorizam no agir, no falar, no pensar e no sentir. O conflito surge quando o desejo do indivíduo não está de acordo ao comportamento padrão culturalmente legitimado, o que pode acarretar para este que transgrede os mais variados tipos de punições. "É certamente muito difícil saber o que cada grupo social faz dessa doutrina, em que medida a admite, recusa ou transforma", percebe Jean-Louis Frandrin (1988, p. 119).

Em $O$ casamento, todas as personagens parecem estar mergulhadas nessa tensão, divididas pela angústia de agirem em função da comunidade na qual estão inseridas, ou de externarem seus próprios ímpetos libidinais. "Tem momentos, momentos, em que eu preciso bater nas paredes, derrubar um poste, rebentar alguém. Você compreende, compreende?", indaga Antônio Carlos para Glorinha, seu amigo prestes a se tornar amante. (RODRIGUES, 2016, p. 113).

Ainda que se sintam sufocados por serem cobrados a seguir uma extensa lista de exigências e, principalmente, honrar proibições impostas pela cultura dominante, os sujeitos representados por Nelson Rodrigues, bem como as pessoas reais do campo da exterioridade, são conscientes - mesmo que talvez não saibam bem o porquê - de que algumas normas jamais devem ser quebradas: "Por princípio, não examino nenhuma cliente, não faço certos exames, sem a presença da enfermeira. Não gosto. Só em último caso e por muita necessidade", posiciona-se o ginecologista de Glorinha, nas vésperas de sua lua-de-mel. (ibdem, p. 45).

Trata-se de normas que, se desrespeitadas no âmbito da cultura do Ocidente medieval, moderno ou contemporâneo, são praticamente impassíveis de receberem clemência jurídica, Revista Graphos, vol. 19, n 2, 2017 | UFPB/PPGL | ISSN 1516-1536 
religiosa e/ou social, como as regras de não matar, não cometer abuso sexual (o qual tenta evitar o ginecologista de Glorinha ao não aceitar atender pacientes sem a presença de uma enfermeira) e não praticar incesto. Outras proibições, por outro lado, ainda que não estejam semanticamente atreladas à noções de horror, uma vez não respeitadas, podem ser compreendidas, por muitos sujeitos e instituições, com sentimentos de decepção, asco e/ou repugnância, como a prática do adultério, a vivência da homoafetividade, o sadomasoquismo e o ato sexual com mais de um parceiro.

Em “Totem e tabu”, texto de 1912-1913, Freud já havia traçado reflexões sobre as configurações da civilização ao fazer uso de estudos antropológicos, biológicos e históricos para explicar a origem da religião e da moralidade. Norteado pela tese de que a gênese da sociedade humana está no assassinato do pai da horda primitiva pelos próprios filhos, o psicanalista revela os modos como algumas regras sociais seguidas por tribos aborígenes resistiram ao passar dos séculos.

"O tabu ainda subsiste entre nós”, sentencia o psicanalista (2012, pp. 15, 42), ao expor que na modernidade o tabu assumiu posições cada vez mais negativas, manteve a função de agir coercitivamente e rejeitar qualquer tipo de motivação consciente. Para Freud, o significado original de tabu se divide em duas direções opostas. Se por um lado quer dizer "santo, consagrado", por outro traduz-se enquanto "inquietante, perigoso, proibido, impuro". Em polinésio, o antônimo de "tabu" é "noa", ou seja, "habitual, acessível a todos". Assim, o tabu estaria, portanto, relacionado ao impedimento da violação do "sagrado", expresso através de restrições e proibições que não precisam ser racionalmente entendidas para serem seguidas.

Fundamentado em si mesmo, o tabu torna-se um poder. Coerção por excelência, ele é o costume e a tradição transformados em lei. "Mas o mandamento implícito por trás das proibições do tabu, que tanto variam conforme o tempo e o lugar, é originalmente um só: 'Guarda-te da ira dos demônios"”. (FREUD, 2012, p. 51). Demônios que se referem mais aos conflitos da sexualidade provenientes da alma humana, do que sobre os anjos que se rebelaram contra o Deus cristão. "O que ele queria dizer é que, em cada família, há trevas que não convém provocar. Quantas casas, quantos lares são varridos de adúlteras, pederastas, incestuosos, epiléticos?", provoca o narrador de $O$ casamento, em ressonância às teorias desenvolvidas pelo psicanalista. (RODRIGUES, 2016, p. 208).

Se o tabu é a interdição de uma prática considerada reprovável, o totem expresso no título do texto de Freud (2012, p. 16) diz respeito a um objeto, um animal, uma planta, uma criatura ou um ser que é internalizado por uma religião, uma tribo, uma comunidade ou 
sociedade enquanto algo ancestral, protetor, sagrado. Nesse viés, o totemismo seria uma instituição social-religiosa "alheia à sensibilidade atual, realmente há muito abandonada e substituída por novas formas, que deixou traços mínimos na religião, nos usos e costumes de povos civilizados de hoje".

Uma vez que já não dispunha de acesso ao homem pré-histórico para desenvolver suas pesquisas de cunho psicossocial, Freud (2012, p. 20) recorreu às tribos consideradas, pelos etnógrafos, como sendo as mais atrasadas e miseráveis, as dos aborígenes da Austrália, no desejo de compreender como surgiram os ideais de moralidade. Nessas tribos canibalescas, a religião é substituída pelo sistema do totemismo, que marca todo o clã com um mesmo ancestral, ou seja, um mesmo totem. Transmitido hereditariamente, por linha materna ou paterna, a relação com o totem "é o fundamento de todas as obrigações sociais para um australiano; ela se sobrepõe ao fato de pertencer a uma tribo, por um lado, e ao parentesco sanguíneo, por outro lado". Desvinculado de um solo ou lugar, seus membros costumam morar separados uns dos outros e convivem harmonicamente com os membros provenientes de outros totens. A parte desse contexto que mais diz respeito a psicanálise, porém, é o fato de que "em quase toda parte em que vigora o totem há também a lei de que membros do mesmo totem não podem ter relações sexuais entre si, ou seja, também não podem se casar. (FREUD, 2012, p. 21, grifos do autor).

Ao compararmos o modelo da instituição totêmica com o da família nuclear moderna, percebemos que uma das leis fundamentais do totemismo se perpetuou: a proibição de relações sexuais entre indivíduos pertencentes a uma mesma unidade original. "Eu não sou incestuoso", afirma Sabino, em $O$ casamento, com a veemência de quem se defende da acusação de um crime (RODRIGUES, 2016, p. 214). A regra de não ceder ao coito com um consanguíneo, no entanto, ainda que muitos acreditem ser originária de nossa própria natureza, está bem mais relaciona às necessidades de estruturação das sociedades patriarcais. Segundo David Friedman (2002, p. 168), "se um homem agir como se tivesse acesso sexual a todas as mulheres sem medo do desafio irá ameaçar a fundação da ordem pública".

É o que defendeu, anteriormente, Freud (2012, p. 242), ao explicar que, nos sistemas totêmicos, existe o mito de que com inveja e temor da liberdade e soberania social e sexual do pai, os filhos se uniram para castrá-lo e usurpar-lhe o poder, cada qual adquirindo uma porção de sua força. Com a morte paterna, a tendência dos irmãos foi a de não se conformar com a força repartida entre eles e desejarem, cada um, vir a se tornar o próprio rei-pai. A consequência de tal conflito foi uma sucessão de crimes familiares que puseram em perigo o senso de comunidade. Ao perceberem a necessidade de restauração da ordem, os fratricidas produziram 
uma reação moral, originária do totemismo e do tabu, a qual, além de prestar homenagens ao pai assassinado - esse passa a assumir a simbologia do totem - os condiciona a desistirem de alcançar o poder dentro de seu próprio clã, tornando as mães, irmãs e primas um desejo proibido. Por meio desse ato de renúncia sexual em prol da progressão da comunidade, surge a religião e, consequentemente, a civilização.

É no interior desse contexto que a família assume, como aponta Mirna Maracajá (2011, p. 66), uma função regulamentadora, a qual civiliza a satisfação do sujeito. E civilizar é, pois, regrar, condicionar, coibir, treinar e controlar desejos. Proibições que começam bem no início, na nossa primeiríssima infância, quando "evidenciou-se um forte desejo de tocar, cujo objetivo era muito mais especializado do que se esperaria. Logo veio de encontro a esse desejo, de fora, a proibição de realizar justamente esse toque", detalha Freud (2012, p. 57, grifo do autor), ao atestar que, em virtude da primitiva constituição psíquica da criança, a proibição não consegue aniquilar o instinto, o qual reprime um dos nossos primeiros grandes desejos, o de tocar, banido para o inconsciente. "Quer tirar a mão? Quer tirar a mão?”, exige Glorinha para o dono dos dedos que ousa tocar-lhes o braço (RODRIGUES, 2016, p. 220).

Em "Três ensaios sobre a teoria da sexualidade", publicado em 1905, Freud recorre a observação que fez de seus pacientes, bem como a sexólogos de sua época, para defender a centralidade do sexo no arco da vida humana, nomeando o estágio em que a criança finalmente tolera as proibições do toque de amnésia infantil.

Ao reprimir os impulsos sexuais da infância, escondendo-lhes os primórdios de sua vida sexual, a amnésia infantil forma poderes psíquicos que "depois se colocarão como entraves no caminho do instinto sexual e, ao modo de represas, estreitarão seu curso (o nojo, o sentimento de vergonha, os ideais estéticos e morais)" (FREUD, 2016, p. 80). Ainda que a civilização, a família e a educação tenham a responsabilidade de construir tais impedimentos, esse desenvolvimento é, também, organicamente condicionado, herdado hereditariamente, e pode, na perspectiva do psicanalista, se produzir sem o auxílio de qualquer instrução, através da "psique das massas".

Desse modo, o adiamento da maturação sexual, iniciado pelas proibições do tocar, está relacionado às prescrições morais que excluem algumas escolhas objetais, como parentes sanguíneos e as pessoas que do infante cuidaram. "Certamente que o mais fácil, para a criança, seria escolher como objeto sexual as pessoas que ama desde a infância" (FREUD, 2016, p. 147). O tabu do incesto, no entanto, conforme discutido anteriormente, surge, resguardado nas leis familiares, enquanto exigência cultural necessária para produzir e preservar as unidades sociais. 
A importância das referências paternas para a esfera do desejo, apesar disso, não se esvai com o processo de maturação individual.

As primeiras experiências de prazer do sujeito se deram no ato da amamentação (ou de seus substitutos), processo em que os lábios infantis foram transformados em zona erógena, estimulada pelo fluxo de leite quente proveniente do seio materno. Freud (2016, p. 85) assegura que se, neste primeiro momento, a atividade sexual se apoia na função alimentar, posteriormente a satisfação sexual se separa da necessidade de nutrição, época em que os dentinhos do bebê começam a nascer e a sucção tende a ser desprestigiada pelo mastigar. A medida em que os anos vão passando, a criança vai se dando conta de que esse momento primevo, em que se sentiu embalada, acalentada, protegida, nutrida e satisfeita através do corpo de seus genitores, não será outra vez vivenciado.

O tabu do incesto formaliza a desilusão, a perda da mãe enquanto objeto de desejo, e a criança, através do período de latência proveniente da amnésia infantil, parte em busca de novas formas de experienciar, uma vez mais, os instantes de prazer e completude perdidos com o surgimento das proibições sexuais. $\mathrm{Na}$ busca por novos objetos que sempre parecem insuficientes para o preenchimento de seus vazios, o sujeito vai encontrando satisfação sexual tanto através do próprio corpo, no que Freud (2016, p. 84) denominou de autoerotismo, como no corpo de terceiros, caso venha a desenvolver uma vida sexual considerada normal para um adulto. Nesse sentido, o encontro de um objeto sexual sempre seria um tipo de reencontro dele, um substituto que reestabeleceria a felicidade que fora perdida.

Assim, as relações infantis que mantivemos com os nossos pais se colocam como decisivas nas futuras escolhas de objetos sexuais por nós tomadas, pois "mesmo quem conseguiu evitar a fixação incestuosa da libido não escapa à sua influência", de modo que "é fácil compreender que toda perturbação desses laços infantis acarreta graves consequências para a vida sexual após a maturação" (FREUD, 2016, p. 151). "Vou-te levar para longe, muito longe. O senhor hoje é meu, papai. Repetiu, baixo, para si mesma: Meu” manifesta Glorinha, "com o coração disparado de felicidade" (RODRIGUES, 2016, p. 203). São justamente das graves consequências de vidas sexuais alicerçadas na quebra de tabus de que tratam, entre outras discussões, as personagens de $O$ casamento, como analisaremos nas páginas seguintes. 


\section{Convidados}

\section{O pai da noiva}

Ainda que pretenda narrar os infortúnios que antecedem a celebração matrimonial de Glorinha e Teófilo, O casamento está centralizado, bem como boa parte da teoria freudiana, na imagem do pai patriarcal. É Sabino Uchoa Maranhão, homem de cinquenta anos, diretorpresidente da Imobiliária Santa Teresinha, quem protagoniza o romance assinado por Nelson Rodrigues (2016, p. 05). Com “obsessivo pudor de ser magro”, Sabino vai reverberando suas vergonhas e constrangimentos morais ao longo de uma narrativa assentada na ação e no diálogo, dois elementos fortemente dramáticos dos quais o escritor pernambucano não abria mão. Nessa estrutura tipicamente melodramática, em que, segundo Jean-Marie Thomasseau (2016, p. 127), a agilidade do enredo, as falas e o espetacular são sobrepostos ao lirismo e ao rebuscamento da linguagem, a intriga e a passionalidade pontuam a trajetória de Sabino e de seus mais importantes convivas no confronto com os seus próprios desejos.

A véspera do casamento da sua filha caçula, especializada e temporalizada em meados dos anos 60 do Rio de Janeiro, é o gatilho para a entrada de Sabino em um estado paranoico que o leva a "tudo dizer, tudo confessar, nada esconder" (DIAS, 2013, p. 91). Na busca por utilizar a linguagem para, mais do que se conhecer, se expurgar, Sabino acaba por atentar contra os outros, revelar sua sordidez, e naufragar na tentativa de construir uma imagem positiva de si. "Sabino! Eu te conheço há trinta anos. E, durante esses trinta anos, você já me disse, umas quinhentas vezes, que é um 'homem de bem'. É, Sabino, você gosta de se apresentar como 'homem de bem'”, desabafa um dos melhores amigos do protagonista, o Dr. Camarinha, um tanto incrédulo diante da integridade moral do outro para quem as generalizações machistas são uma marca: "A mulher é mais pornográfica que o homem”, "não existe família sem adúltera”, “certas expressões, a mulher de classe não usa". (RODRIGUES, 2016, pp. 27, 32, 38, 68).

A moralidade cristã, o machismo e o conservadorismo de Sabino passam a ser ainda mais desafiados quando, em uma das primeiras cenas do romance, o Dr. Camarinha, o qual além de amigo, é médico da família, o segreda que o seu genro, Teófilo, prestes a se casar com Glorinha, é homossexual: "Vi teu genro, teu futuro genro, o Teófilo, beijando na boca o meu assistente. Meu assistente, aquele rapaz que você conhece, o Zé Honório. Ninguém me contou, eu vi”, ao que Sabino, perplexo, reage: “O senhor me diz isso a 24 horas do casamento?”. E, mesmo diante da promessa de infelicidade de sua filha caçula, permite que o casamento de Glorinha aconteça sem grandes intervenções contrárias de sua parte, afinal de contas, convidara 
"metade do Rio de Janeiro. Um dos padrinhos era Ministro e senhora. Casamento a rigor. Pela primeira vez, ia usar casaca. E imaginava a cara do Ministro [...] se, de repente [...] não houvesse mais casamento" (ibdem, pp. 19, 22, 26).

Começamos, por meio desse contexto, a compreender que, para a personagem em tela, bem como para os sujeitos civilizados descritos por Freud (2010), há uma forte predisposição a legitimar a ordem social da qual faz parte, mesmo que, para isso, ponha em detrimento os próprios desejos e ideais de felicidade. Fator que coloca em questão a estabilidade de pensamento e honestidade com que os sujeitos lidam e julgam a si mesmos e aos outros em suas ações cotidianas.

Se, por um lado, Sabino defende o posicionamento machista de que "não existe família sem adúltera”, por outro ele é obrigado a se deparar com o fato de que a sua filha está casando com um homem que o é. Se, por sua vez, ele assume a defesa pública e incessante de que é um "homem de bem", logo em seguida está, diante do mesmo interlocutor para quem destinou autoelogios, se negando a cancelar o casamento da filha, deixando-a casar com um possível homoafetivo, por não ter coragem de enfrentar, na esfera social, a vergonha de cancelar a tão aguardada festa de casamento sob a justificativa do erro, do engano, da "mácula" homoafetiva que chegou até os seus.

O impasse vivenciado por Sabino diz respeito a três das questões anteriormente defendidas, neste artigo, por Freud: a sexualidade, o tabu e a civilização. É através do desejo sexual que Teófilo se vê incapacitado de manter os códigos sociais anteriormente firmados com Glorinha, ao assumir o papel de seu noivo numa relação afetiva expressamente tradicional, de modelo monogâmico e heterossexual. O desejo do genro de Sabino, para ampliar o problema da família conservadora em questão, é homoafetivo, o que por si só já o torna um tabu, visto ser este um sentimento que inibe as probabilidades de reprodução e continuidade da espécie tão defendidas pela tradição. Atrelada ao crime do adultério (o qual, quando experimentado, por um homem, em uma conjuntura heteressexual, não tende a ser gerador de tantos danos), a proibição da homoafetividade, quando transgredida por Teófilo, respinga nas barreiras da civilização, representadas, na obra, pelo estabelecimento da família nuclear padrão. Diante da exposição da fragilidade das normas delimitadas pela instituição do casamento, facilmente quebradas por desejos impetuosos, Sabino, por estar em posição patriarcal, se vê obrigado a fingir que nada está acontecendo, consciente (ou não) de que, aconteça o que acontecer, é seu papel lutar para que a cultura civilizatória se mantenha de pé - ainda que erguida apenas na zona das aparências. 
As rupturas de Teófilo para com os dogmas calcificados na tradição, no entanto, passam a assombrar Sabino que, com receio de um dia também vir a se deixar levar pelos fascínios do desejo, se ancora nos ensinamentos deixados pelo seu próprio genitor: "O pai queria que ele fosse um homem de bem. E, desde então, a vontade do defunto o acompanhava por toda a parte" (RODRIGUES, 2016, p. 07). E repete, como se na repetição fosse capaz de convencer a si mesmo: "Eu não teria essa coragem. Não aprovo, não aprovo infidelidade. Eu tive outra criação". A imagem do pai, porém, costuma vir em suas lembranças entrelaçadas não apenas pelo afeto do filho que anseia respeitar os exemplos deixados pelo referente masculino, mas associadas, também, a recordação da repugnância de quando ele ainda era vivo: "começou a ter nojo do cheiro do pai quando estava para morrer". (ibdem, pp. 75, 08).

Para Angela Maria Dias (2013, p. 96), em A forma da emoção, a desordem e as oposições de Sabino em relação ao próprio pai parodiam as reflexões de Freud em "O mal-estar na civilização" sobre a conexão entre o sentimento de culpa e a morte do pai primevo: “Assentado na 'ambivalência primordial' dos filhos, que tanto o amavam quanto o odiavam, o remorso, depois do assassinato, passa a ser a sensação prevalente, já que satisfeito o ódio, manifesta-se o amor pelo pai, antes em latência". Se em vida o pai de Sabino lhe provocava asco, morto, assume a simbologia sagrada do totem, enquanto ser representante dos preceitos culturais que devem ser mantidos e repassados na/pela tradição.

Mais uma vez, no entanto, as ideias de moralidade de Sabino se veem refutadas pela sua própria experiência. Ainda adolescente, e triste pela recente orfandade paterna, ele se dirige até um prostíbulo no objetivo de perder a virgindade:

A morte do pai não lhe saía da cabeça. Teimou, com uma boca de choro: Quero a senhora. Então, a cafetina gorda e nostálgica ergueu-se, num movimento ágil de menina. Toda ela ria, riam os seios, as ancas, a barriga, e riam as pulseiras. E ele já não pensava mais na morte do pai. (RODRIGUES, 2016, p. 07)

Apesar da tentativa de Sabino iniciar sua vida sexual com a prostituta, a consumação do ato não acontece em decorrência de uma impotência momentânea. E, novamente, percebemos, corporificadas na estruturação desta personagem rodriguiana, as teorias psicanalíticas. Com o pai morto, o filho pode, finalmente, ter a sua mãe, a responsável por sua primeiríssima experiência de prazer - através da amamentação - só para si (Cf.: FREUD, 2016). No romance, a figura materna vem a ser projetada na cafetina, mulher mais velha, com um corpo não correspondente ao padrão de beleza social, mas possuidora dos mesmos cuidados que uma mãe zelosa teria para com o seu menino, chamando-o, inclusive, de filhote: "Vem cá, vem, ó filhote. Isso é nervoso. Mas passa. Deita aqui” (RODRIGUES, p. 08, grifo nosso). A assimilação da 
prostituta enquanto referencial materno chega a ser observada, também, na impotência sexual de Sabino para com ela, o que expõe, para essa personagem, a efetivação das interdições relacionadas ao incesto.

Aos vinte anos, Sabino casou-se com Maria Eudóxia, dois anos mais jovem do que ele. Tiveram quatro filhas: Marília, Dirce, Arlete e Glorinha. Possuíam uma vida financeiramente confortável. Eram cristãos. Mas tinham um casamento infeliz. "Minha mulher é uma santa. Mas, sei lá, não tem um certo tato" (ibdem, p. 106, 21). Nas vezes em que Maria Eudóxia tentou manifestar sua libido, no entanto, foi contraditoriamente repreendida por ele: "Na cama conjugal, quando Eudóxia queria falar, interrompia: - Cala a boca! Cala a boca!” (ibdem, p. 68).

Insatisfeito com a mulher que escolhera para firmar os códigos matrimoniais, descobrimos, através de um narrador em terceira pessoa, que Sabino não é tão contrário ao adultério como ele defende em público:

Há dois anos que, uma vez por mês, duas no máximo, vai ao apartamento de Haddock Lobo. A inquilina era a viúva de um oficial da Marinha, mãe de duas garotinhas. A presença das crianças dava a Sabino a sensação de lar, de família. Antes de ir, telefonava: Não deixe de pôr lençóis limpos. (ibdem, p. 61)

A referida viúva, no entanto, não é amante de Sabino. Dona Sara é apenas a responsável por fornecer um de seus quartos para que ele realize seus encontros extraconjugais. Percebemos, porém, que, mesmo burlando as normas da família tradicional quando parte em busca de satisfazer o seu desejo, Sabino, ainda assim, é cercado pelos valores familiares que lhe foram impressos. Parte para a profanidade, adulterando contra Maria Eudóxia, mas o sentimento de culpa se manifesta na exigência de que o seu crime seja praticado em ambiente familiar: "A presença das crianças dava a Sabino a sensação de lar, de família". E até mesmo o aviso de "não deixe de pôr lençóis limpos" denuncia a sua necessidade de mascaramento, dissimulação da realidade, como se, uma vez que estivesse protegido pelo falso verniz de uma "família de bem", qualquer proibição pudesse ser quebrada.

No tempo presente da narrativa, a escolhida da vez para visitar os compartimentos domésticos do apartamento de Dona Sara, é Noêmia, uma secretária assistente de Sabino. "Ele pensa: 'Sou uma besta. Vou fazer a maior burrada da minha vida. Essa mulher vai espalhar pra todo mundo. Vai dizer que eu dei em cima. É capaz de telefonar pra Eudóxia." (ibdem, p. 54). Mas o desejo de encontrar satisfação em um novo objeto sexual, externo às barreiras de seu matrimônio, para além da "falta de tato" de Maria Eudóxia, o faz procurar outras maneiras de sentir prazer, ainda que elas não lhe ofereçam a garantia de completude: "Na véspera do casamento da filha, estava, ali, à espera de uma mulher que não desejava" (ibdem, p. 62). 
Para Freud (2016, p. 151), como vimos anteriormente, o processo de encontrar um objeto é completado no sujeito após a puberdade, quando as zonas genitais já assumem a primazia sexual e, no lado psíquico, o instinto perde a mãe, sob a forma do seio materno, enquanto objeto. Na busca incansável de um novo objeto que substitua o primeiro perdido, o humano parte, como exemplificado por Sabino, fazendo tentativas, sempre na vontade de reestabelecer o prazer que fora interditado na primeira infância. Daí a origem das insatisfações de Sabino, possuidor de um vazio que parece que nunca será preenchido por nada nem ninguém. Casa-se com Maria Eudóxia, mas logo seus referenciais físicos e psicológicos se colocam em desacordo com aquilo que ele, sem bem o saber, procura. O corpo da esposa não o atrai, seu toque - tão diferente do experienciado nos tempos da primeiríssima infância - não o estimula. Segue, assim, em busca de novas candidatas a objetos de satisfação. Com a ajuda de uma viúva, passa a receber mulheres, ao longo de dois ou três anos, que só o realizam no momento fortuito do gozo. A solidão, a falta, a lacuna, permanecem incólumes, parecendo se acentuar a cada tentativa fracassada de encontro do objeto. Em se tratando do adultério,

A sensação de felicidade ao satisfazer um impulso instintual selvagem, não domado pelo $\mathrm{Eu}$, é incomparavelmente mais forte do que a obtida ao saciar um instinto domesticado. O caráter irresistível dos impulsos perversos, talvez o fascínio mesmo do que é proibido, tem aqui uma explicação econômica. (FREUD, 2010, pp. 34-35).

Essa sensação de felicidade atingida na transgressão de uma regra, de um tabu, é vivenciada pelo personagem em discussão não apenas através da prática do adultério. Já o fora obtida, também, na consumação da homoafetividade, quando era mais jovem, como ele bem o confessa, na cama, para Noêmia: "Uma vez, quando eu era garoto, eu e um menino fomos tomar banho juntos. Banho de rio, no Trapicheiro. Eu tinha 12 anos e ele, 14. O menino era mais forte que eu. Tiramos a roupa. E, então, ele me agarrou” (RODRIGUES, 2016, p. 69).

Diferente de como Maria Eudóxia poderia reagir, Noêmia deixa Sabino falar. No espaço permissivo de uma cama de casal extraconjugal, permite que ele expresse suas fantasias, admita suas transgressões. Nesse instante da narrativa, o leitor mais atento compreende o porquê de Sabino, apesar de incomodado, não ter ido até as últimas consequências no enfrentamento para com o seu genro, recém flagrado beijando outro homem. A ideia transpassada por esse encadeamento de situações é, mais uma vez, a de que, para a família tradicional e, principalmente, para o patriarca, tudo é permitido, desde que vivenciado sob o manto das "boas aparências". Trancado no interior de um quarto de uma família socialmente respeitada - a viúva de um militar - Sabino sente que, finalmente, pode ser e dizer quem o é. 
Sobre o desejo sexual por um sujeito de mesmo sexo, Freud (2016, p. 20), há mais de cem anos, já esclarecia que "existem homens para os quais o objeto sexual não é a mulher, mas o homem, e mulheres para as quais esse objeto não é o homem, mas a mulher. Tais pessoas são chamadas de Konträsexuale, ou melhor, invertidos".

Ainda que hoje a terminologia inversão possa vir a ser considerada politicamente incorreta, por carregar o sentido daquilo que é contrário, tendo sido deturpada, até hoje, enquanto o contrário de "normalidade", o significado estabelecido por Freud (ibdem, p. 22) é o de sexualidade contrária a norma heterossexual padrão observada em sociedade. Por mais que tenha caído em desuso, a nomenclatura se destina para os sujeitos compreendidos, na contemporaneidade, enquanto gays e/ou homoafetivos. Para Freud (ibdem), por outro lado, os invertidos poderiam se dividir em absolutamente invertidos (quando seu objeto sexual se fixa em sujeitos do mesmo sexo), invertidos anfígenos (quando não há exclusividade de escolha de objeto por meio do sexo) e invertidos ocasionais, definição mais aproximada da experiência de Sabino: quando em determinadas "condições externas - entre as quais se acham, primeiramente, a inacessibilidade do objeto sexual normal e a imitação - podem tomar uma pessoa do mesmo sexo como objeto sexual e ter satisfação com ela no ato sexual."

Norteado pela angústia inconsciente de encontrar um objeto de desejo que nunca chega a ser verdadeiramente achado, Sabino, desde o início do romance, vai condicionando seus investimentos libidinais para a filha que vai casar: "Não pense que Glorinha é uma filha como outra qualquer. Não. Glória é outra coisa. Olha, dr. Camarinha, vou the fazer uma confissão. Só gosto de Glorinha.” (RODRIGUES, 2016, p. 26). Criada com zelo, mimo, e uma atenção especial do pai, Glorinha, que corresponde ao carinho exagerado de Sabino em iguais proporções, provoca ciúmes na mãe e nas irmãs.

"A filha ia se casar no dia seguinte - e virgem. Não queria pensar no defloramento" (ibdem, p. 13). O incômodo para Sabino da iminência do casamento de Glorinha, porém, não se limita apenas ao fato de que ela possa estar se unindo matrimonialmente a um homoafetivo. Sente-se inquieto com a chegada da certeza de que a sua filha caçula não será mais sexualmente pura. "Ninguém mais se casava virgem. Só Glorinha" (ibdem).

Glorinha personifica a idealização feminina das fantasias de Sabino. Pura, incólume, bela, virgem, jovem, doce. Ela é a representação ideal, aos olhos do pai, da mulher romantizada pelo cristianismo e reverberada através da imagem de Maria, mãe de Jesus, mulher tão acima das demais que teve a capacidade de gerar um filho sem a necessidade do intercurso sexual. A certeza de que a filha não será mais virgem, porém, deixa Sabino cada vez mais tenso. Tão 
preocupado que começa a duvidar de suas próprias idealizações: "Naquele momento, Sabino teve a tentação quase insuportável de perguntar: 'Glorinha é virgem? Eu sei que é. Mas gostaria que o senhor, como médico, dissesse que é virgem, sim’ Conteve-se, porém” (ibdem, p. 18).

Ao escolher não perguntar ao ginecologista da filha, seu amigo íntimo, se ela ainda é virgem, Sabino faz uma recusa à realidade inquietante e decide permanecer com as respostas criadas confortavelmente por sua própria imaginação. Se todas as mulheres que conhece são tratadas por ele com desprezo, Glorinha é a única a se manter conservada em uma redoma de estima. Admirada não apenas por ser sua filha. Admirada por ser virgem, diferente de suas irmãs casadas.

“Olha um dos retratos. Um retrato nunca é a pessoa, mas 'uma coisa', 'outra coisa', outra pessoa. E, no entanto, um pouco de Glorinha se insinuava ali, um pouco do seu impecável frescor" (ibdem, p. 13). No curso da narrativa, as fantasias e a realidade de Sabino e de Glorinha vão se alternando, problematizando os limites das normas da tradição e das leis do desejo. Ao olhar para o retrato da filha e enxergá-la como "outra coisa, outra pessoa", Sabino começa, sutilmente, a trazer a temática do incesto para o centro da narração. E, na medida em que esse assunto vai ganhando densidade, a atmosfera do romance se torna cada vez mais apocalíptica.

\section{A noiva}

Considerada como sendo a mais bonita filha de Sabino, Glória, carinhosamente chamada por todos de Glorinha, o diminutivo enaltecendo-lhe o lado juvenil, demonstra bastante ansiedade na véspera de seu casamento com Teófilo. Declaradamente encantada pelo pai, e vivendo um pouco às turras com a mãe e as irmãs, a personagem feminina de maior protagonismo em $O$ casamento costuma despertar instintos sexuais por onde passa:

O diabo eram os rapazes, os moços da companhia. Depois que Glorinha passava, eles cochichavam entre si as obscenidades mais delirantes. Tempos atrás, alguém escrevera o nome da menina na parede do mictório. E não só o nome. O pior eram os desenhos hediondos, os palavrões (RODRIGUES, 2016, p. 33).

Mas Glorinha, ainda que goste, finge não dar atenção para os olhares que atrai sobre si. Para Freud (2016, p. 49), “a impressão ótica continua sendo o caminho pelo qual a excitação libidinal é despertada com mais frequência” e, talvez por isso, ela seja uma mulher vaidosa. Mesmo estando prestes a se tornar casada, Glorinha não se policia na hora de exalar sensualidade e mexer com as fantasias alheias. É nesse sentido que um dos principais conflitos narrativos em torno desta personagem surge, quando, através da sua melhor amiga, Maria Inês, 
Glorinha se aproxima de Antônio Carlos, o filho do Dr. Camarinha: "Pensava no filho do ginecologista. Quando Glorinha fez 17 anos, houve uma festa na casa de Sabino. Ela conhecia Antônio Carlos, assim, de anedota. Não se sabia o que era fato e o que era folclórico na vida desse rapaz" (ibdem, p. 93).

Antônio Carlos era namorado de Maria Inês, mas, no presente da diegese, estavam brigados. Na véspera do casamento de Glorinha, os três, sob o intermédio de Maria Inês, promovem um encontro. Nessa oportunidade, Glorinha não demora a perceber que "o folclore" em torno da vida e da personalidade de Antônio Carlos não se tratava de mero falatório. Agressivo, violento, impetuoso, viciado em álcool e drogas, ele vem a representar, para Glorinha, o contrário de tudo o que ele aprendera, através da Igreja e da sua família, sobre as noções de certo e errado.

Se, por meio da instituição do casamento ensejado por Glorinha, nós temos os símbolos da tradição e do sagrado corporificados na forma de uma estrutura relacional, em Antônio Carlos encontramos a profanação personificada. Ao saber por Maria Inês que ele a fizera transar com outro homem na frente dele, Glorinha se revolta: "Entre um homem e uma mulher, vale tudo. Mas o que é que ele fez? Põe outro dentro do quarto. Manda o outro deflorar você e fica assistindo. Sabendo que você era virgem. Nojento!" (ibdem, p. 107). E, é diante desse sujeito sem moralismos sociais e sexuais que, às vésperas de seu casamento, Glorinha é ardilosamente posicionada por um narrador interessado em ver o embate de uma moça de classe média da década de 60 , confrontada pelos fascínios do desejo em oposição às diretrizes da civilização.

Ao saber que Maria Inês havia contado para Glorinha que ele tinha a forçado a transar com outro rapaz na sua frente, Antônio Carlos exige ter o direito de explicação. Combinam uma volta de carro pela Lagoa, mas Glorinha, apesar de ter aceito o encontro com o filho do seu ginecologista, se coloca irredutível: “A mim, não precisa explicar nada. Maria Inês sabe a minha opinião. E, além disso, olha: você vai perder o seu tempo. Eu não acredito em você”. Surpreendido pela atitude determinada de Glorinha, Antônio Carlos é possuído por um rompante intempestivo de passionalidade: "Vocês saltam. Então, eu... Está vendo aquele poste ali? Aquele, o último? Eu vou meter o carro naquele poste, a toda. A 120. Ouviu, sua Glorinha?" e, enquanto as duas passageiras do carro ouviam-no geladas, com medo, ele ameaçou: "Comigo não tem esse negócio de mulher, não. Apanha homem, apanha mulher, apanha todo mundo. $\mathrm{E}$ nem acredito que você seja cabaço coisa nenhuma. Agora desce, desce e vai pra puta que te pariu” (ibdem, pp. 109, 110). É quando Glorinha, finalmente, volta atrás, desculpando-se, dizendo que talvez o tenha interpretado de maneira equivocada. 
A cena é medida pela crescente agressividade de Antônio Carlos, inicialmente voltada para si mesmo, no desejo de se matar jogando o carro violentamente contra um poste, depois direcionada, mais precisamente, para Glorinha, com ofensas, insultos e promessas de agredi-la fisicamente. Nesse contexto, torna-se pertinente resgatar os dizeres de Freud (2016, p. 52, grifos do autor) a respeito do temperamento masculino: A sexualidade da "maioria dos homens mostra um elemento de agressividade, de inclinação a subjugar, cuja significação biológica estaria na necessidade de superar a resistência do objeto sexual por algum outro meio além de fazendolhe a corte". Sendo assim, os ímpetos violentos de Antônio Carlos seriam uma maneira diferenciada de chamar-lhe atenção, de atraí-la sexualmente.

O sadismo também é um componente demarcado tanto na composição psicológica da personagem de Antônio Carlos, como também verificado na cena em análise. Na linguagem corrente, "o conceito de sadismo vai de uma atitude simplesmente ativa, depois violenta ante o objeto sexual, até o vínculo exclusivo da satisfação com a subjugação e o mau tratamento desse objeto" (ibdem, p. 52). Fatores percebidos na atitude ativa com que Antônio Carlos exige que Glorinha ouça a explicação que ele tem para lhe dar, acentuada por uma postura violenta perante ela, lançando-a ameaças e subjugando-a, não se importando em atentar, inclusive, contra a "honra" de uma noiva às vésperas de seu casamento: "nem acredito que você seja cabaço coisa nenhuma".

"Se você soubesse o bem que me fez! Você me salvou. E olha. Eu não estava brincando. Juro e Maria Inês sabe. Eu ia me estourar naquele poste [...] Escuta, Glorinha. Você agora acredita em mim. Você acredita? Então, vamos ao tal programa", convida, mais uma vez em tom de exigência, Antônio Carlos, agora mais tranquilo, ao que Glorinha rebate: "Mas que programa? Nem sei que programa. É o quê?" e ele, em tom misterioso, apenas responde: "Se eu disser, perde a graça. A graça é a surpresa. Aposto que você vai gostar”. (RODRIGUES, 2016, p. 114).

O referido programa vem a configurar uma das passagens mais icônicas do romance, ocorrida na metade da narrativa, o que dá um novo frescor, além de mais agilidade, a matéria que está sendo contada, conforme analisaremos nos próximos parágrafos.

Após muitas estratégias persuasivas utilizadas por Antônio Carlos e Maria Inês, Glorinha finalmente aceita ir para a tal programação misteriosa: "Eu vou a esse programa, porque quero e porque sei o que faço. Essa é uma. Agora outra: estou fugindo de um homem, um homem que, esse, sim, é minha tara” (ibdem, p. 116). Questionada por Maria Inês se ela está se referindo ao noivo, Glorinha nega e confessa: "Um dia, eu saí de casa. Sem calça, sem 
sutiã, com o vestido em cima da pele. Fui ao escritório desse homem. E, lá, enquanto ele virava as costas para atender o telefone, eu arranquei o vestido" (ibdem, p. 117). A conversa sobre este assunto encerra com Glorinha lamentando o fato de não ter acontecido nenhum tipo de relação sexual com o homem que ela havia surpreendido.

A revelação de que esta personagem, prestes a subir no altar, está "fugindo" de um homem, que não é o seu marido, para quem chegou a fazer uma surpresa de cunho sexual, aparecendo nua no escritório dele, dialoga com o que temos proposto nas discussões desse trabalho. As regras da sociedade parecem nunca se afinar com os desejos dos sujeitos representados por Nelson, fazendo com que instituições como a do casamento surjam, para eles, revestidas pela função de "válvulas de escape" ou "fugas", como a própria Glorinha direciona. O conflito é acentuado quando, mesmo se condicionando às diretrizes da cultura, o indivíduo não resiste a necessidade de dar vazão a suas vontades mais transgressoras, como a de uma noiva que surpreende um outro homem, que não é o seu noivo, com provocações e convites sexuais. Nesse viés, Freud (2010, p. 58) coloca que "o impulso à liberdade se dirige, portanto, contra determinadas formas e reivindicações da civilização, ou contra ela simplesmente". No caso de Glorinha, suas ações, ao serem guiadas pelo desejo, agem em desarmonia com as formas da relação conjugal tradicional e, consequentemente, questionam as bases constituintes do ideal civilizatório.

A "programação" preparada por Antônio Carlos para Glorinha é rica em representações dessas tensões entre normatividade e sacrilégio. O lugar para onde eles vão é a casa de Zé Honório, assistente do pai de Antônio Carlos no consultório ginecológico, justamente o que foi visto aos beijos com o noivo de Glorinha. "Olha aqui. É o seguinte: a besta do Zé está com vergonha de você, Glorinha [...] Você sabia que ele era bicha?”, questiona Antônio Carlos, para uma Glorinha surpresa. (ibdem, p. 118). Recepcionados por Zé Honório, que "estava, no fundo da sala, com um copo pela metade, com uma sunga mínima e o resto nu", Antônio Carlos pede que eles adiantem logo o que haviam combinado. (ibdem, p. 119). É quando o anfitrião, após beber o resto do uísque que estava em sua mesa, começa a contar a sua história para os recémchegados:

É o seguinte, seguinte. Um dia, o meu pai chegou em casa mais cedo. Chega mais cedo e passa no meu quarto. Entra de repente. Eu tinha 12 anos. Entra e me vê com um garoto, um pouco maior do que eu. Os dois nus. Eu era a mulher do outro. O velho tirou o sapato e correu com o garoto às sapatadas [...] Durante trinta dias, apanhei de chicote. E o velho dizendo: 'Engole o choro, engole o choro!' Cheguei à perfeição de apanhar sem um suspiro. Quando completou o mês, ele me disse: 'Se fizer isso outra vez, eu te mato, te mato!' [...] O velho não me largou nunca mais. Uma vez, me esbofeteou na mesa: 'Não fala fino. Fala como homem!' (RODRIGUES, 2016, p. 123).

Revista Graphos, vol. 19, n 2, 2017 | UFPB/PPGL | ISSN 1516-1536 
As possibilidades de análise para o fragmento em recorte são múltiplas, principalmente na atualidade, em que tanto as teorias psicanalíticas, bem como as que dizem respeito exclusivamente as dos gêneros e das sexualidades, estão em ebulição. Apesar disso, optamos por nos manter focados no objetivo principal deste trabalho, ao perceber o modo como a instituição familiar, na função de controladora do desejo humano, tende a ser uma extensão das leis sociais sancionadas na/pela civilização.

Identificado, na perspectiva da teoria freudiana, enquanto absolutamente invertido, Zé Honório, desde criança, tem o seu desejo direcionado para objetos de mesmo sexo que o seu, mesmo sendo tolhido pela aspereza e violência do pai, que no interior do seu lar, é responsável por se tornar um representante da cultura, do Estado e da tradição. Vigilante e punitivo, o pai de Zé Honório, como todo patriarca preocupado em defender - consciente ou inconscientemente - os ideais civilizatórios, exige que seu filho siga a cartilha de tudo o que foi estabelecido no âmbito da sociedade do que deve ser um homem: "Não fala fino!”, "engole o choro!", “fala como homem!'”. Para Freud (2012, p. 47), “a maioria das proibições diz respeito à capacidade de fruição, à liberdade de movimento e comunicação". Proibido, sem compreender ao certo o porquê, de vivenciar o prazer que o satisfaz, Zé Honório cresce revoltado em meio a tanta repressão.

"Isso ou aquilo é proibido, não sabemos por quê, e também não lhes ocorre fazer a pergunta; eles apenas as cumprem como algo óbvio, e estão convencidos de que uma transgressão será punida automaticamente, de forma severa", observa Freud (ibdem), em comum acordo ao que é plasmado pelas atitudes violentas e sem explicação tomadas pelo pai de Zé Honório ao surpreender o filho de 12 anos com outro garoto na cama.

Neste ponto, a ação da narrativa segue por caminhos inesperados tanto para a personagem de Glorinha, quanto para boa parte dos leitores de Nelson, até mesmo para os mais acostumados com as suas peripécias e subversões sexuais, o que vem a explicar a proibição da obra por parte da ditadura militar.

Zé Honório conduz Glorinha, Maria Inês e Antônio Carlos até o quarto onde está o seu pai, sob uma cama, de pijamas, à beira da morte. "Velho, você não está dormindo. Não está dormindo, nem morreu. Eu sei que tu vê e ouve. Então, escuta. Escuta o que eu vou te dizer. Esperei 15 anos por esse momento. Está ouvindo, velho?", e deita-se na cama, ao lado do doente, para falar em seu ouvido: “Aqui tem duas meninas. Eu nunca, nunca, quis ser homem. Durante toda a minha vida, eu quis ter xoxota como as meninas, como todas as meninas" e prossegue, em sua vingança filial, detalhando o plano que porá em prática: “Agora, eu vou 
fazer, na tua frente. Vou fazer na tua frente com um chofer de ônibus, o que eu fiz com aquele menino. Vou fazer aquilo aqui dentro. Tu vendo, vendo e ouvindo". (RODRIGUES, 2016, p. 126). E o faz.

“Zé Honório volta com o Romário. É um mulato forte, lustroso, de ventas obscenas. Entra de boca aberta, olho incandescente. Tem a coxa plástica, elástica, vital, como a anca de um cavalo" (ibdem, p. 127). A masculinidade padrão expressa no corpo do objeto sexual escolhido por Zé Honório rivaliza com os ideais do "ser homem" defendidos pelo seu pai e, consequente, pela civilização. Ao ser colocado, pela personagem de Zé Honório e pela narrativa, em posição de homoafetividade, o "mulato forte, lustroso, de ventas obscenas", estereotipadamente associado ao que a tradição defende enquanto representação de heterossexualidade masculina, revela para o patriarcado o que ele insiste em negar: a denúncia de que o desejo é uma instância particular do humano, a qual não precisa corresponder às determinações e expectativas da sociedade. É por isso que um homem, mesmo sendo viril, "de coxa elástica, plástica, vital como a anca de um cavalo", pode ser possuidor de desejos por outro homem, como tenta explicar Zé Honório para o seu pai, recorrendo aos métodos mais sádicos, perversos e vingativos possíveis.

Para além das altas doses de sadismo contidas nessa atitude voltada contra o próprio pai, o que nos remete ao desejo de morte do pai primevo anteriormente apontado por Freud quando explicava o surgimento do tabu do incesto, há uma liberação libidinal de exibicionismo e voyeurismo marcadamente controladas pelas leis da civilização. Freud (2016, p. 50) delimita o exibicionismo no prazer em ser visto, ao passo que o voyeurismo está para o prazer em ver. Com o tabu do incesto concretizado em nossa cultura, filhos passam a não poder se mostrar sexualmente para os seus pais, tornando esta mais uma das regras da tradição transgredidas por Zé Honório. "Não deixa, Antônio Carlos! Não deixa! Se você é homem, quebra a cara desse puto!” (RODRIGUES, 2016, p. 127), implora Glorinha que, diferente de Antônio Carlos, não está nenhum pouco interessada em se posicionar como voyer. "A força que se opõe ao prazer em olhar, e que eventualmente é suplantada por este, é o pudor (como antes sucedeu com o nojo)" (FREUD, 2016, p. 51).

O pudor de Glorinha, no entanto, se destina apenas na recusa da cumplicidade com o projeto de vingança engendrado por Zé Honório contra o pai homofóbico. Os apelos para que Antônio Carlos, enquanto homem, assuma os ideais da civilização e estabeleça, através da sua força, o retorno da ordem dominante são o estopim para que os seus próprios desejos se desprendam das amarras sociais e, inesperadamente, venham à tona: "Novamente, ele a solta e 
novamente ela o esbofeteia. Ele apanha de braços arriados. E, então, enlouquecida, a garota une o seu corpo ao dele, beija-o na boca: Eu não quero ver! Me leva contigo!” (RODRIGUES, 2016, 127).

Antônio Carlos a carrega para um outro quarto da casa, Maria Inês os acompanhando. "Eu quero ser tua, mas sozinha. Não quero que Maria Inês veja. Sozinha, meu amor", pede Gloria para Antônio Carlos, que a desobedece: "Vem, Maria Inês, vem!”. Os três entram no quarto, Antônio Carlos joga Glorinha em cima da cama, e ordena: "Agora todo mundo nu! Tira a roupa, Maria Inês! Tira, Glorinha!’. Maria Inês o obedece, Glorinha não reage, mas se deixa ser despida pelo filho do seu ginecologista, que faz uma última exigência: "Agora vocês vão se beijar na minha frente. Na boca. Começa, Maria Inês. Na boca". As duas relutam, mas o homem não desiste: "Maria Inês, faça o que eu mando! Você não disse que era minha escrava? Não disse até que era capaz de arranjar mulher pra mim? Então, beija Glorinha na boca!”. E as duas, contrafeitas, obedecem. Rolam, lutam, gemem e choram. Então Glorinha, "numa frenética agilidade, passa para cima da outra, beijando e mordendo". (RODRIGUES, 2016, pp. 128, 129).

De acordo com Sábato Magaldi (2010, p. 25) Nelson se viu levado a pintar, em consequência da sociedade machista brasileira, a permanente frustração feminina. "Ele não fez proselitismo, não levantou a bandeira de reivindicações feministas: limitou-se a fixar o fenômeno, e o espectador que tirasse as suas conclusões". Na passagem em análise de $O$ casamento, somos conduzidos ao primeiro ápice da curvatura transformacional da personagem Glorinha, uma mulher de família conservadora, às vésperas do seu casamento, vivenciando as experiências sexuais mais proibitivas para a sua posição. Ainda que as suas reações possam funcionar como uma expurgação da frustração para com o patriarcado, como defende Magaldi, a libertação de seus desejos, na narrativa, só se torna possível pela autorização do homem, representando por Antônio Carlos, sempre determinando o que ela deve ou não fazer.

Nessa conjuntura, atentamos para o fato de que, conforme demonstra a ficção rodriguiana, as leis da civilização problematizadas por Freud são sumariamente criadas por homens e para eles. Ao seguir a proposta temática do romance em tela, percebemos que a homoafetividade, seja ela masculina ou feminina - conforme expuseram Sabino e Glorinha -, pode vir a ser plenamente autorizada quando se coloca em serventia do gozo heterossexual do macho.

O espaço da narrativa também torna-se um facilitador para a liberação de desejos e rupturas de convenções das personagens nele inseridas. A casa de Zé Honório é descrita como um lugar marginalizado, antigo, deteriorado, distante do centro metropolitano: "Samambaia, 
tinhorão, lacraia, tudo do tempo da onça. Casa de 1800 e lá vai fumaça” (RODRIGUES, 2016, p. 117). Nesse lugar desprovido de olhos punitivos e/ou vigilantes, invisibilizado pela degradação do tempo, as normas da sociedade acabam por ser mais facilmente esquecidas e, consequentemente, quebradas, como demonstra Antônio Carlos, Zé Honório, Maria Inês e Glorinha, a qual, sem saber, retribui o adultério cometido pelo seu noivo.

E, como já era de se esperar, ainda na posição ativa, decidindo o curso da relação sexual entre ele, Glorinha e Maria Inês, Antônio Carlos finalmente tira a virgindade da noiva de Teófilo: "Quando ele a beija no ombro, Glorinha sente as entranhas geladas. Depois, foi levada, carregada. Quer que ele a rasgue. [...] Glorinha não tinha medo da dor e queria que doesse. [...] Glorinha prende o grito: Continua, continua!" (p. 133).

Para Freud (2012, p. 57), após a calcificação dos tabus e do desenvolvimento da civilização, proibição e instinto foram ambos mantidos, "o instinto, porque estava apenas reprimido, não abolido, a proibição, porque, quando cessasse, o instinto viria à consciência e alcançaria a realização". Estabelecida essa situação não resolvida, do persistente conflito entre proibição e instinto, o instinto, por permanecer no sujeito, tende a buscar formas de burlar as regras sociais e se libertar do recalque, tal e qual acontece com Glorinha às vésperas de um casamento com um homem que não a satisfaz. "Ela fora deflorada e não estava nervosa, nem sentia medo, nenhum, nenhum [...] E, antes de ser deflorada, fora possuída por uma menina" (p. 151). E, assim como o pai, Glorinha encontra como subterfúgio para as doutrinações normatizadoras do desejo, o recurso da dissimulação, do mascaramento e das aparências.

Ainda na casa de Zé Honório, todos ficam sabendo que o pai dele não resistiu ao plano de vingança arquitetado pelo filho e veio a óbito. É o estalo responsável por trazer todos de volta para a dureza da realidade normativa, controladora, punitiva e cheia de imposições, tão diferente da atmosfera de libertinagem que eles haviam arquitetado. Glorinha lembra do seu pai. Se atenta para o dia de noiva que a aguarda. E volta para a sua residência, para as programações do casório, para os agendamentos da lua de mel na condição de esposa que não se casa virgem. Deflorada por um homem e "possuída por uma menina". Ao chegar em casa, Glorinha se depara com o pai:

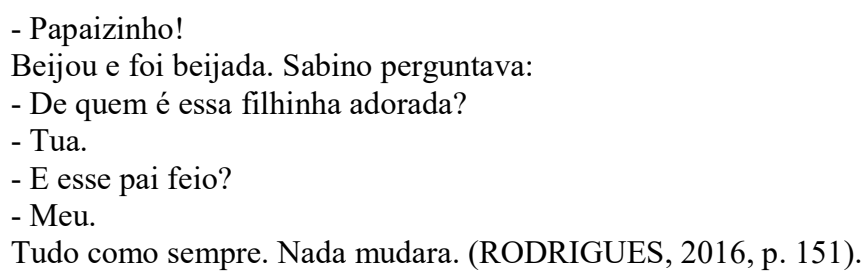


Os modos como Glorinha se dirige ao pai, fazendo questão de carregar nos trejeitos infantis, chamando-o de "papaizinho" e se aprazendo ao ser intitulada de "filha adorada", revelam uma psique ainda bastante presa aos estágios da sexualidade em que os objetos sexuais do infante são direcionados, conforme debatemos nos estudos de Freud (2016), para os seus genitores. O desejo inconsciente, da parte de Glorinha, em direção a Sabino, parece ser ainda mais explicitado através das considerações trazidas pelo narrador: "Tudo como sempre”, ou seja, por mais que Glorinha tenha se deitado com outro homem, seu pai continua lhe demonstrando afeto, permanecendo na posição de seu antigo objeto, "nada mudara".

A relação de carinho exagerado mantida entre os dois chega a incomodar as irmãs de Glorinha, enciumadas por não receberem, do genitor, as mesmas dosagens libidinais recebidas pela caçula: “Até parece que você é filha única. Nós não existimos. Você não pode usar calcinha de nylon e nós podemos usar o diabo, andar sem calça, nuas, que papai nem liga. Papai só gosta de você. Ou estou mentindo?” (RODRIGUES, 2016, p. 92). Para Freud (2016, p. 105), uma das motivações da disputa familiar passíveis de serem aplicadas para essas mulheres seria o que ele defendeu, contrariando as feministas mais radicais, enquanto inveja do pênis:

A suposição de que há o mesmo genital (masculino) em todas as pessoas é a primeira das teorias sexuais infantis singulares e prenhes de consequências. Pouco adianta, para a criança, que a ciência biológica tenha de dar razão a seu pré-conceito, reconhecendo o clitóris feminino como um genuíno substituto do pênis. A menina não se utiliza de tais rejeições quando enxerga o genital diferente do menino. Ela se dispõe imediatamente a reconhecê-lo e é vencida pela inveja do pênis, que culmina no desejo, importante em suas consequências, de ser também um garoto. (FREUD, 2016, p. 105).

Nesse sentido, o ciúme das irmãs de Glorinha é, na perspectiva da psicanálise freudiana, um desejo ambivalente. Se, por um lado, elas invejam a posição da irmã caçula, na vontade de serem elas as receptoras do exacerbado amor paterno - detentor do falo/poder que elas não possuem, por outro, persiste o desejo de que a soberania da tradição seja respeitada e, para isso, assumem o papel de vigilantes comportamentais. "O resultado final deve ser um direito para o qual todos - ao menos todos os capazes de viver em comunidade - contribuam com o sacrifício de seus instintos" (FREUD, 2010, p. 57).

As hipóteses a respeito da probabilidade de realmente haver desejos incestuosos entre Glorinha e Sabino, aumentam quando a primeira faz para o segundo uma indagação que, segundo ela, tinha vontade de fazer desde criança: "Como é que o senhor pode gostar de mamãe? O senhor gosta mesmo de mamãe? Eu não acredito. Gosta?” Atônito, Sabino questiona como uma filha pode se referir nesses modos sobre a própria mãe, ao que a filha rebate: " $\mathrm{E}$ 
porque é minha mãe eu tenho que gostar? Sou obrigada? Pois fique sabendo que eu não gosto de minha mãe" (RODRIGUES, 2016, p. 205).

A falta de apreço pela mãe, da parte de Glorinha, traduz-se, psicanaliticamente, em rivalidade materna, visto ser ela inconscientemente possuidora da crença de que não Maria Eudóxia, mas ela, Glorinha, é quem deveria estar no controle, no domínio e no poder que só uma matriarca possui em relação a suas filhas hierarquicamente desprivilegiadas. Alocadas nessa atmosfera incestuosa em plena civilização, descobrimos, mais uma vez através de Freud (2012, p. 61), que

\footnotetext{
o desejo original de fazer o proibido continua a existir nos povos em que há o tabu. Eles têm, em relação a tais proibições, uma atitude ambivalente, nada gostariam mais de fazer, em seu inconsciente, do que infringi-las, mas também tem receio disso; receiam justamente porque querem, e o temor é mais forte que o desejo.
}

Talvez por isso, Glorinha, já na abertura do desfecho da narrativa, faltando muito pouco para o seu casório, faça um convite para Sabino que decidirá o curso de suas trajetórias: “O que interessa é que nós estamos aqui e eu adoro o senhor. E sabe pra onde nós vamos agora? Pra uma praia deserta" (RODRIGUES, 2016, p. 205). Os danos e resolução desse problemático convite, analisaremos no tópico a seguir, o qual traz uma reflexão a respeito dos finais destinados às principais personagens de $O$ casamento.

\section{O grande dia}

\section{Dilaceração e desejo}

A chegada do casamento de Glorinha culmina na exposição do desejo ocultado pelas principais personagens do romance, momento reservado para as últimas páginas da obra. A impressão é a de que, quanto mais o instante decisivo do enlace matrimonial entre ela e Teófilo se aproxima, mais tensas e insustentáveis se tornam as relações de todos os envolvidos - direta ou indiretamente - com os futuros noivos. A ideia de que haverá o casamento, porém, sempre é lembrada, tanto na marcação temporal de que fazem as personagens, quando em seus conflitos psicológicos quando recordam das normas sociais que delimitam a constituição de uma família nos moldes tradicionais. De um lado, Sabino, o pai da noiva, adúltero, de perfil incestuoso, prestes a conduzir a filha caçula para o altar, onde irá entregá-la nas mãos de um possível "pederasta"; de outro, Glorinha, a noiva que não ama o noivo, jura gostar de um homem que não a quer, escolhe o matrimônio por conveniência, perde a virgindade, às vésperas da cerimônia, com um amigo e uma amiga, e direciona uma adoração infantil e excessiva para o 
próprio pai. Montado o drama da moderna família tradicional, dividida entre a secularização e a normatividade, investigaremos, agora, quais desfechos estão reservados, na ficção rodriguiana, para os que ousam transgredir as leis civilizacionais.

Glorinha chega de carro com Sabino em uma praia deserta, a pedido dela. As ameaças de que uma exposição do desejo incestuoso possa acontecer a qualquer instante, seja por parte do pai, seja por parte da filha, ganham uma crescente dramática que atingem, incialmente, uma revelação feita por ela:

O senhor sabe que mamãe sempre me deu banho. Até hoje, ou até outro dia. Dizia que eu não sabia me lavar direito. Aquela conversa. E, depois, me enxugava, passava talco no corpo todo. Passava entre as pernas, dizendo: "Você transpira aí, pode dar assadura.” [...] Até que, na última vez, depois de me enxugar. Está ouvindo, meu pai? Minha mãe me agarrou, me virou e me deu, na boca, um beijo de língua. Como se fosse um homem, papai! (RODRIGUES, 2016, p. 212).

A confissão de que já fora abusada pela mãe faz com que compreendamos mais um dos porquês de Glorinha afirmar detestá-la. Outro ponto importante para ser percebido nessa passagem, é a percepção de que Glorinha, na estrutura do seu desenvolvimento sexual, já assimilou as interdições culturais e psicológicas do incesto, direcionando, para tais práticas, sentimentos de raiva e nojo, em consonância ao que alertara Freud (2016). Por outro lado, a reação de Sabido, ao ouvir da própria filha que Maria Eudóxia tentou violenta-la, é de negação: "É mentira! Mentira! Sou católico praticante, cristão. Eu não acredito que uma mãe seja lésbica da própria filha. Não acredito!” (RODRIGUES, 2016, p. 212).

Glorinha, confusa por não ter encontrado solidariedade por parte do pai, tenta convencêlo, inutilmente, de que não está mentindo, mas ele se posta irredutível. Suas verdades chegam a parecer pré-fabricadas, como na ênfase constante que ele dá ao fato de ser cristão, deixando a entender que tal condição seria capaz o suficiente de absolver suspeitas sobre qualquer sujeito. Esta posição defensiva escolhida por Sabino, no entanto, parece dizer muito mais dele do que da sua esposa. Ao querer poupar Maria Eudóxia de supostas acusações de incesto, Sabino está, no fundo, defendendo a si mesmo: "É mentira! Mentira! Sou católico praticante", justifica, como se ele fosse o verdadeiro acusado de Glorinha.

No curso ágil da ação narrativa, permeada, prioritariamente, por diálogos, Sabino aproveita os desmascaramentos do instante para também fazer uma confissão: "Vou-te dizer mais, ouve, vou-te dizer mais. Tua mãe teve um amante. Me traiu. Eu perdoei isso" (RODRIGUES, 2016, p. 212).

E, mais uma vez, o espaço ficcional atua em cumplicidade para com as personagens deste enredo, estimulando-as a verbalizarem e manifestarem quem de fato o são. A praia 
deserta, longe do centro urbano controlado diuturnamente pelas regras da civilização, surge como o cenário ideal para Sabino, mesmo na posição imponente de patriarca, trazer à tona as fissuras de sua relação conjugal, ao admitir que já foi traído e perdoou o adultério de sua esposa. Maria Eudóxia, por sua vez, a matriarca da principal família representada no romance, é negativamente pintada pelos membros pertencentes ao seu núcleo genealógico. Enquanto mãe, não respeitou o tabu do incesto e, no papel de esposa, não cumpriu com a norma da exclusividade sexual determinada pela monogamia dos casamentos cristãos.

Glorinha não se surpreende com a informação trazida por Sabino a respeito de Maria Eudóxia. Parece já possuir consciência de que, os membros da sua família, são seguidores de dois tipos de códigos sociais: um seguidor da norma patriarcal, publicamente explicitado; outro transgressor das proibições culturais, mascarado. Mas ao perceber a franqueza do momento, Glorinha aproveita o despejar de verdades para confessar ao pai, em tom de culpa, que gosta de uma pessoa que deveria ser sagrada para ela. Sabino se pergunta se a sua filha está apaixonada pelo Monsenhor amigo da família. "Teve vontade de perguntar: 'A menina que tirou a roupa detrás da porta - é você? Você ficou nua e descalça para o Monsenhor?' Mas não perguntou nada. Passou a mão nas próprias lágrimas" (ibdem, p. 212). Mas sabia que as suas suposições estavam corretas.

Prefere, apesar disso, mais uma vez, recusar os indícios de realidade. Muda, estrategicamente, de assunto, dando vazão as suas fantasias libidinosas. Diz que, assim como ela, a filha, ele também se sente atraído por uma pessoa que deveria the ser sagrada. Glorinha questiona quem. É o estopim necessário para Sabino se desvincular de todas as proibições culturais que seguraram o seu desejo incestuoso pela filha caçula até aquele segundo: "Súbito, agarra a menina. Dá-lhe um violento beijo na boca”. Para o desespero e surpresa de Sabino, porém: "Glorinha foge do novo beijo" (ibdem, p. 213).

Para Ângela Dias (2013, p. 100), a reação de Glorinha, antes provocadora e insinuante, e agora assustada e acusadora, pouco importa na economia geral do acontecimento da manifestação do incesto praticado pelo pai. “Tem mais a ver com a própria dissimulação que a caracteriza, do que com o seu perfil de incestuosa não assumida”. Dissimulação, esta, tanto constatada no ódio que sente pela mãe, na postura sedutora com que insiste em tratar o pai e na própria indiferença ao noivo com quem decidiu se casar. Diagnóstico, também, atestado por Sabino: "Você me trouxe pra cá. Uma cilada. Fez insinuações. No automóvel, veio com a mão no meio da minha coxa. [...] Glorinha, você queria me excitar. Eu não sou incestuoso" (RODRIGUES, 2016, p. 213). 
Ao seduzir e, depois de conquistado, rejeitar o pai, Glorinha reage, vingativamente, mais do que a Sabino, contra as imposições do patriarcado, fazendo-o provar de todos os dissabores que ele mesmo engendra ao cercear o desejo humano.

Ao ser obrigado, pela filha, a beber do próprio veneno que fabrica, Sabino reatualiza a condição do pai primevo defendido por Freud (2012), atacado pela rebeldia de uma horda inconformada com as posições e posicionamentos do genitor ancestral. O ineditismo trazido pela literatura de Nelson para este contexto está no fato de que, aqui, no espaço da modernidade, as antigas tribos, transformadas, hoje, em famílias, se voltam contra o pai moderno para questionar as leis sociais decorrentes da morte do pai primevo. Se, nas primeiras organizações humanas, a morte simbólica do pai fora necessária para o surgimento das regras civilizatórias, hoje ela é reivindicada como forma de libertação dos aprisionamentos sexuais trazidos pelo progresso e, ainda, representados, em cada lar, pela figura do patriarca.

De volta a ação dramática, após conseguir se desvencilhar do beijo incestuoso do pai, Glorinha segue em busca da mãe, que a trata com secura e indiferença. Para a mãe da noiva, mais importante do que atentar para o dilaceramento dos laços familiares, é manter a concretização do matrimônio: "Minha filha, olha aqui. Não quero saber de nada. Sim? Não me conta nada. Deixa sair esse casamento. Depois, a gente conversa, está bem?" (ibdem, p. 224). Desse modo, compreendemos que, nascida em uma família de sujeitos que se recusam a lidar com os acontecimentos da realidade, excessivamente preocupados com a opinião pública e com o fingimento de que seguem as normas da igreja e do Estado, Glorinha aprende a ser, ela mesma, a personificação de toda a dissimulação aprendida na observação de seus tutores incestuosos.

Em meio ao silenciamento em torno do incesto parental, vem o desfecho trágico da amante de Sabino, Noêmia, brutalmente assassinada por Xavier, seu outro amante: "Quando empurrou a porta, Noêmia estava de costas, usando a serrinha de unhas. Xavier tira o punhal. Veio por trás e afundou-lhe o punhal nas costas, até o cabo" (ibdem, p. 234). Ao descobrir que Noêmia não é de sua exclusividade, Xavier, até então tendo sido representado como um sujeito pacato, um tanto passivo, que abdicara de boa parte de sua vida nos préstimos e cuidados de uma esposa doente, cria coragem para manifestar sua masculinidade de maneira sanguinária: "o homem não pode ser tão humilde", reflete enquanto pratica o feminicídio, "homem tem que se impor" (ibdem, p. 228).

Desenganado com a perda objetal de Noêmia, única fonte potencial canalizadora de sua libido, Xavier passa a acreditar que a sua existência já não é passível de sentido. E, como se não bastasse, após cometer o assassinato da assistente de Sabino, sacrifica, também, a sua 
esposa doente: "Atirou no meio do sorriso. A mulher apenas baixou a cabeça. E, depois, tombou, ainda sorrindo". Tomado cada vez mais pelo desespero, Xavier sofre com o peso de alucinações representantes do que a sociedade reserva para quem pratica um assassinato, decidindo, desse modo, por um fim, também, em sua própria vida: "Imaginou que multidões da Central, do Maracanã, estavam batendo na sua porta. E, então, introduziu na boca o cano do revólver e puxou o gatilho" (ibdem, p. 242).

Para Freud (2012, p. 72), assim como o incesto, o assassinato, mesmo quando praticado contra um inimigo, também é um de nossos tabus ancestrais: "Entre os monumbos, na Nova Guiné alemã, todo aquele que matou um inimigo na guerra torna-se 'impuro'”. Oliveira \& Silva (2012, p 09), por outro viés, ao corroborarem com a ideia defendida neste artigo, notam que o que prevalece na resolução plasmada nos crimes envolvendo Noêmia, Xavier e a sua esposa é um forte sentimento de intolerância e ódio "exalados pela repressão dos desejos; do mundo sufocante em que vivem e que despertará o instinto (quase primitivo) de destruição do outro".

Destruição simbólica praticada pelas filhas mais velhas de Sabino: Marília, Dirce e Alerte. Inconformadas com o fato dele, além de ter bancado a grandiosa festa de casamento da caçula, ter presenteado o genro com um cheque significativo, se unem querendo também elas desfrutarem de benefícios financeiros proporcionados pelo pai, o encurralando em um jogo sórdido e chantagista:

Papai, você se lembra daquela festa? Festa do meu aniversário, em Lins de
Vasconselos? Enquanto o pessoal dançava, Silene saiu para o quintal. Já não estava
se sentindo bem. E, lá, teve o ataque. Ninguém viu, só o senhor. Sim, da varanda, o
senhor viu Silene cair. Desceu, sem dizer nada. Carregou a menina para a parte mais
escura. Eu apareci na janela. O senhor é que não me viu. Tudo aconteceu debaixo da
janela. Deflorador, sim, deflorador. E de uma menina com ataque e durante o ataque.
Silene tinha 13 anos e o senhor parecia louco. (ibdem, p. 251).

Ao resgatarem um crime praticado pelo pai que, como tantos outros, fora propositalmente ignorado pela família, as filhas de Sabino conseguem convencê-lo a também dar-lhes um cheque. Nessa passagem, vem a denúncia de que, para a família tradicional pintada por Nelson, as profanações exercidas por seus membros só devem ser postas em evidência quando algum benefício pessoal e, no recorte dado, financeiro, puder ser retirado de tal atitude. Concedida a extorsão, as aparências civilizacionais devem voltar a ser mantidas. Para Dias (2013, p. 94), as transgressões sexuais cometidas por Sabino vão, pouco a pouco, caracterizando sua loucura, a qual se torna responsável pela deterioração de seus laços familiares. É “a grande aposta do romance: a explosão do sagrado, ou de sua paródia degradada, mais ainda assim, atuante, no universo da cidade deteriorada pela mais valia cotidiana”. 
Adúltero, incestuoso, pedófilo, maníaco, criminoso e, acima de tudo, hipócrita. Esse é o quadro final exposto pela narrativa rodriguiana para o "homem de bem", pai cristão, líder da família tradicional e defensor da moral e do conservadorismo.

Apaixonado pela ideia de ser "santo", e sentindo-se cada vez mais culpado, Sabino encontra no Monsenhor, amigo da família, o conselho promovedor do início de sua redenção: "Quer saber o que eu diria, se falasse amanhã? Diria que todos nós devemos assumir a nossa miserabilidade. Entende? O homem e a mulher devem juntar as próprias chagas” (ibdem, p. 255).

Mesmo dilacerada, desestruturada, disfuncional, com relações existentes apenas na esfera da superfície, a família de Sabino segue em defesa do modelo tradicional de vida, representado, na obra, principalmente, pelo casamento de Glorinha e Teófilo, que de fato acontece: "Mais tarde, alguém diria que ele entrara, na igreja, de braço com a filha, pálido como um santo. Viu toda a cerimônia com tédio desesperador" (RODRIGUES, 2016, p. 261). A ineficiência das leis matrimoniais, ancoradas na tradição, porém, demonstram não dar conta das complexidades e singularidades do desejo humano, conforme expresso por Sabino através do tédio sentido durante a cerimônia de casamento da filha e, também, em acordo ao defendido por Freud (2016), há quase cem anos, em "O mal-estar na civilização".

Após a consumação do casamento de Glorinha, motivado pelas palavras do Monsenhor, Sabino decide ser punido por seus crimes, ainda que, para isso, não tenha coragem de assumir, publicamente, quais tabus ele transgredira. "O mais singular é que quem chega a violar uma proibição dessas adquire ele mesmo a característica do que é proibido, como que assumindo toda a perigosa carga". (FREUD, 2012, p. 48). Desse modo, reconhecendo "suas chagas", Sabino faz uso do assassinato cometido por Xavier para pagar suas dívidas para com a civilização: "Vim, aqui, confessar meu crime. Eu, Sabino Uchoa Maranhão, matei, ontem, no meu escritório, por ciúmes, a minha secretária Noêmia. Essa moça era a minha amante", professa, diante do delegado e da imprensa (RODRIGUES, 2016, p. 262). Uma vez que o casamento de Glorinha já havia acontecido e a tradição matrimonial, enfim, estava resguardada, restava a punição para quem não vive de acordo com as diretrizes hegemônicas. Conservadores, os próprios Xavier e Sabino se encarregam de cumprir a justiça que norteia as estruturas da civilização.

E, assim, mais uma vez validando as palavras de Freud (2012, p. 55), encerra-se o romance $O$ casamento, acentuando a normatividade ancestral de que "quem infringiu um tabu, 
ao tocar em algo que é tabu, torna-se ele próprio tabu e ninguém pode entrar em contato com ele".

Eis a base do dilaceramento familiar rodriguiano.

\section{O que Deus uniu...}

Sabino, que era traído por Maria Eudóxia, a traía com Noêmia, que traía Sabino com Xavier, que traía a esposa enferma nas vésperas do aclamado casamento carioca de Glorinha Uchoa, que era traída por Teófilo enquanto o traía com Antônio Carlos, que traía Maria Inês que, até onde sabemos, não traía, conjugalmente falando, ninguém. O que parecia ser um poema de Carlos Drummond de Andrade às avessas se colocou, na verdade, como sendo a espinha dorsal do enredo sórdido e erótico de $O$ casamento.

Unidos sob a graça de discursos conservadores e cristãos, todos os casais articulados por Nelson Rodrigues na obra que aqui fora discutida se portaram, no interior de suas relações afetivo-sexuais tradicionais, como sujeitos indiferentes, perversos, mentirosos, infiéis, adúlteros e, acima de tudo, hipócritas.

Enquanto pais, não atenderam às expectativas relacionais de seus filhos e foram de contra aos papéis paternos socialmente determinados, chegando ao ápice da inversão moral ao manifestarem desejos incestuosos pelos que criaram. Enquanto filhos, agiram contrários as posições de poder calcificadas pela hierarquia familiar, voltando-se com sedução, mentiras, manipulação, perversidade e extorsão de seus genitores, reagindo contra as imposições da civilização.

Ao acreditarem na importância de se validar e perpetuar as diretrizes patriarcais, as personagens acabaram por entrar em conflito com os seus próprios desejos, os quais não conseguiam ser domesticados, descumprindo, em partes, uma das principais funções das proibições sociais: tolher o instinto. Apenas em partes porque, mesmo não sendo seguidas, as normas culturais do Ocidente, ainda que ineficientes na prática, demonstraram sua eficácia na dissimulação encenada na performance pública, o que acabou por lhe garantir vitalidade e manutenção, representadas, com afinco, na consumação do casamento de Teófilo e Glorinha.

Similar ao procedimento terapêutico em psicanálise, esta ficção, em conformidade ao que percebeu Pereira (2012, p. 53), fez uso dos elementos da narrativa, como a trama, o tempo e o espaço, para apresentar "a lógica do desvelamento da verdade, da revelação gradativa e analítica" das personagens, as quais se expuseram, através de discursos e ações, na complexidade do texto literário.

Revista Graphos, vol. 19, n² 2, 2017 | UFPB/PPGL | ISSN 1516-1536 
$\mathrm{Na}$ teia semântica do romance analisado, Sabino, Maria Eudóxia, Noêmia, Xavier, Glorinha, Teófilo, Zé Honório, Antônio Carlos e Maria Inês agiram motivadas pela tensão entre seguir/renegar, correspondência temática tanto da obra de Nelson Rodrigues como dos estudos teóricos deixados por Sigmund Freud.

Nessa perspectiva, os conflitos entre reprimir ou dar livre vazão aos impulsos sexuais se alicerçaram na esfera do desejo, inerente ao sujeito humano independentemente de delimitações espaço-temporais. As normatizações do instinto e os problemas decorrentes do cerceamento libidinal, longe de ser um problema apenas resultante do advento da modernidade e da expansão do sistema capitalista no Brasil, como defendeu Alexandre Godoy (2012), se mostrou ser uma questão ancestral, presente na humanidade desde as bases da criação da civilização, após o estabelecimento dos tabus.

Nossa análise pôde confirmar, também, a noção freudiana de que "não existe povo e estágio de cultura que tenha escapado aos danos do tabu" (FREUD, 2012, p. 49). Mesmo tendo sido escrita e representada na modernidade carioca brasileira da década de 60, a obra traz personagens que violam tabus tradicionalmente graves, como os do incesto e do assassinato, tornando os transgressores, eles mesmos, também tabus, uma vez que teriam o perigoso atributo de tentar outros a seguirem os seus exemplos. "Por que lhe deveria ser permitido o que a outros é proibido? Ele é, portanto, realmente contagioso, na medida em que todo exemplo convida à imitação, e por isso deve ser evitado" (FREUD, 2012, p. 62). Socialmente banidos, seja através da morte e do aprisionamento físico, Xavier e Sabino exerceram, através de suas próprias ações motivadas por sentimentos de culpa, as punições que o Estado e a cultura já lhes reservavam.

Outras proibições, como as do adultério, do sexo com mais de um parceiro, do sadismo, masoquismo, voyeurismo, exibicionismo e homoafetividade, também foram quebradas pelas personagens que desfilaram em $O$ casamento, dilacerando as bases normativas da família tradicional em benefício da libertação desenfreada do desejo. Talvez por isso, como também acreditou Ângela Dias (2013, p. 91), essa obra tenha sido "tão visitada pelo atraso autoritário, por sua objetividade na apresentação das cenas, pela crueza na exposição de problemas psíquicos-afetivos da burguesia, pela economia de meios que desfia um grande número de acontecimentos explosivos", tudo tendo ocorrido, no plano ficcional, em uma extensão de tempo bastante restrita: a véspera de um casamento cristão, monogâmico, heterossexual, totalmente em desalinho com o desejo de seus perpetradores. 


\section{Referências}

DIAS, Ângela Maria. A forma da emoção. Rio de Janeiro: 7Letras, 2013.

FREUD, Sigmund. "Totem e tabu”. In: Totem e tabu, contribuição à história do movimento psicanalítico e outros textos (1912-1914). São Paulo: Companhia das Letras, 2012.

. "O mal-estar na civilização". In: O mal-estar na civilização, novas conferências introdutórias à psicanálise e outros textos (1930-1936). São Paulo: Companhia das Letras, 2010 .

. "Três ensaios sobre a teoria da sexualidade". In: Três ensaios sobre a teoria da sexualidade, análise fragmentária de uma histeria ("O caso Dora") e outros textos (19011905). São Paulo: Companhia das Letras, 2016.

GODOY, Alexandre Pianelli. Nelson Rodrigues: o fracasso do moderno no Brasil. São Paulo: Alameda, 2012.

MAGALDI, Sábato. Nelson Rodrigues: dramaturgia e encenações. São Paulo: Perspectiva, 2010.

MANGO, Edmund Gómez \& J-B. Pontalis. Freud com os escritores. São Paulo: Três Estrelas, 2013.

MARACAJÁ, Myrna Agra. "Parentalidades à la carte e a utopia pós-sexual". In: SILVA, Antonio de Pádua Dias da (Org.). Literatura contemporânea e homoafetividade. João Pessoa: Realize Editora; Editora Universitária da UFPB, 2011.

OLIVEIRA, Cibelle Araújo \& SILVA, Enaura Quixabeira Rosa. "O poder destruidor do desejo”. In: TOMAZ, Jerzuí Mendes Tôrres \& MALUF, Sheila Diab (Org.). O legado de Nelson Rodrigues: reflexões. Maceió: EDUFAL, 2012.

PEREIRA, Victor Hugo Adler. Nelson Rodrigues, o freudismo e o carnaval nos teatros modernos. Rio de Janeiro: 7Letras, 2012.

RODRIGUES, Nelson. O casamento. Rio de Janeiro: Nova Fronteira, 2016.

. "Vestido de noiva". In: Teatro completo de Nelson Rodrigues 1: peças

psicológicas. Rio de Janeiro: Nova Fronteira, 1981a.

. “Álbum de família”. In: Teatro completo de Nelson Rodrigues 2: peças míticas. Rio de Janeiro: Nova Fronteira, 1981 b.

. "O beijo no asfalto". In: Teatro completo de Nelson Rodrigues 4: tragédias cariocas. Rio de Janeiro: Nova Fronteira, 1989.

RECEBIDO EM 25-05-2017

APROVADO EM 20-06-2017

Revista Graphos, vol. 19, n 2, 2017 | UFPB/PPGL | ISSN 1516-1536 